\title{
Humerus distalis vég törött betegeink kezelési eredményei az AO alapelvek tükrében
}

\author{
DR. LAKATOS ADRIENN, DR. LENKEI BALÁZS, DR. UNGVÁRI GÁBOR
}

\section{ÖSSZEFOGLALÁS}

A szerzők vizsgálatának célja az volt, hogy igazolják az AO alapelvek fontosságát a distalis humerus törések kezelésében. A vizsgálathoz a 2017.06.01-2018.05.31 között, a B.-A.-Z. Megyei Központi Kórház és Egyetemi Oktató Kórház Traumatológiai Osztályán operált humerus distalis vég törött betegek adatait dolgozták fel. Retrospektív elemzés történt, amely során az eseteket az AO törésbeosztás és saját pontozási rendszer szerint értékelték. Telefonos kérdőív alapján a QuickDash (QD) értéket, fájdalmat és a betegek elégedettségét (vizuális analóg skála - VAS 1-10) rögzítették. A vizsgálat a mútét után 12-24 hónappal történt. Csoportosították őket a törés típusa, a repozíció minősége, és a behelyezett implantátumok szerint. Az áttekintett idő alatt 53 sérültet operáltak humerus distalis vég törés miatt. A betegek átlagéletkora 61 év volt, 73\%-ban nők szenvedtek el ilyen sérülést. A vizsgálat statisztikailag bizonyította, hogy a megfelelő repozíció és a stabil rögzítés pozitívan befolyásolja a funkcionális kimenetelt. A C típusú törések esetében a logikusan várható gyógykimenetellel szemben jó funkcionális eredményekkel találkoztak. Ennek lehetséges magyarázata az, hogy egy komplikáltabb törés megoldásához előszeretettel választ az operatőr szélesebb feltárást és nagyobb stabilitást biztosító implantátumot.

\section{Kulcsszavak: $\quad$ Könyöksérülés; Humerus distalis; Töréskezelés; Retrospektív vizsgálat; Vizsgálati eredmények;}

A. Lakatos, B. Lenkei, G. Ungvári: Results of patients with distal humerus fractures regarding the AO principles

The authors' aim was to prove the importance of the AO principles in case of the fracture of the distal humerus. Patients with distal humeral fractures were examined whose surgeries took place between 01.06.2017 and 31.05.2018 in the Traumatology Department of B.-A.-Z County and University Teaching Hospital. In this retrospective study the cases were evaluated according to the AO Classification and a self-made scoring system for the reduction. The patients were asked to fill out a questionnaire including questions of QuickDASH (QD), pain and satisfaction levels (VAS). They were divided into groups according to the type of fracture, quality of the reduction and the implant. During this time 53 patients were operated because of distal humerus fracture. The average age was 61 years and $73 \%$ of them were women. The questionnaire was filled out in 29 cases. Statistical proof was found that correct reduction and absolute stabile fixation affect positively the functional outcome. Interestingly patients with C type fractures showed better functional results than expected. The possible explanation is that it is more likely for the surgeon to choose bigger approach to achieve good reduction and an implant that provides enough stability to start early active mobilization.

Keywords:

\author{
Elbow Joint - Injuries/Surgery; \\ Fracture fixation - Instrumentation/Methods; \\ Humerus - Injuries/Surgery; \\ Recovery of function; Treatment outcome;
}




\section{BEVEZETÉS}

A humerus distalis végének törése az összes törés 2\%-át teszi ki. Előfordulása bimodális megoszlást mutat, miszerint a 12-19 év közötti fiatalok, valamint a 60 év felettiek szenvednek el leginkább ilyen sérülést. Míg fiatalkorban nagy energiájú trauma hatására alakul ki, addig idősebb korban az álló helyzetből való elesés is elegendő a törés elszenvedéséhez $(1,3,7)$. Vizsgálatunk során a Borsod-AbaújZemplén Megyei Központi Kórház és Egyetemi Oktatókórház Traumatológiai Osztályán operált humerus distalis vég törött betegeink adatait néztük át. $A O$ referenciaosztály lévén az $A O$ alapelveket helyeztük előtérbe.

\section{ANYAG ÉS MÓDSZER}

Vizsgálatunkhoz a 2017.06.01-2018.05.31 között, osztályunkon operált humerus distalis vég törött betegeink adatait dolgoztuk fel. Retrospektív adatgyűjtés történt, majd a betegekkel telefonon keresztül kérdőívet töltettünk ki, amely tartalmazta a QuickDASH
(QD) pontrendszer kérdéseit, valamint a fájdalom és elégedettség mértékét is rögzítettük 1-10-ig terjedő vizuális analóg skálán (VAS). Figyelembe vettük a törések típusát az AO törésbeosztást használva, a repozíciós helyzetet általunk kialakított pontrendszert alkalmazva, valamint a behelyezett implantátum típusát is. A törés típusa szerint külön vizsgáltuk az $A O$ beosztás alapján az $A, B$ és $C$ típusú töréseket. A repozíció minősége szerint 10 (anatómiai), 9 (közel anatómiai) és 8 (kompromisszumos) pontos csoportokat hoztunk létre. A pontozáshoz a posztoperatív röntgenfelvételen figyelembe vettük a humerus-trochlea szöget, valamint lépcső vagy hiatus jelenlétét a trochlea és capitulum ízületi felszínén. A pontlevonások az I. táblázatban összefoglaltak szerint alakultak.

A behelyezett implantátumok szerint elkülönítettük a minimál invazív csavaros osteosynthesiseket (1. ábra), a kisebb feltárással járó egyoldali lemezes rögzítést csavarral kiegészítve (2. ábra), valamint az olecranon osteotomiával végzett kettős lemezelést (3. ábra) $(4,8)$. Szignifikanciát Student-féle t-teszttel számoltunk $(p=0,05)$.

I. táblázat A humerus distalis vég törött betegek repozíciós helyzetének értékeléséhez használt pontrendszer

\begin{tabular}{|c|c|c|c|c|}
\hline 10 pont & Nincs levonás & -1 pont & -2 pont & -3 pont \\
\hline $\begin{array}{l}\text { Humerus- } \\
\text { Trochlea szög }\end{array}$ & $\begin{array}{l}\text { Anatómiai } \\
\text { helyzet }\end{array}$ & $10-20^{\circ}$ & $0-10^{\circ}$ & \\
\hline Trochlea & $\begin{array}{l}\text { Anatómiai } \\
\text { helyzet }\end{array}$ & $\begin{array}{l}1 \text { mm-es hiatus } \\
\text { vagy lépcső }\end{array}$ & $\begin{array}{l}2 \text { mm-es hiatus } \\
\text { vagy lépcső }\end{array}$ & $\begin{array}{c}3<\mathrm{mm} \text {-es vagy } \\
\text { lépcső }\end{array}$ \\
\hline Capitulum & $\begin{array}{c}\text { Anatómiai } \\
\text { helyzet }\end{array}$ & $\begin{array}{c}1 \text { mm-es hiatus } \\
\text { vagy lépcső }\end{array}$ & $\begin{array}{c}2 \text { mm-es hiatus } \\
\text { vagy lépcső }\end{array}$ & $\begin{array}{c}3<\text { mm-es vagy } \\
\text { lépcső }\end{array}$ \\
\hline
\end{tabular}




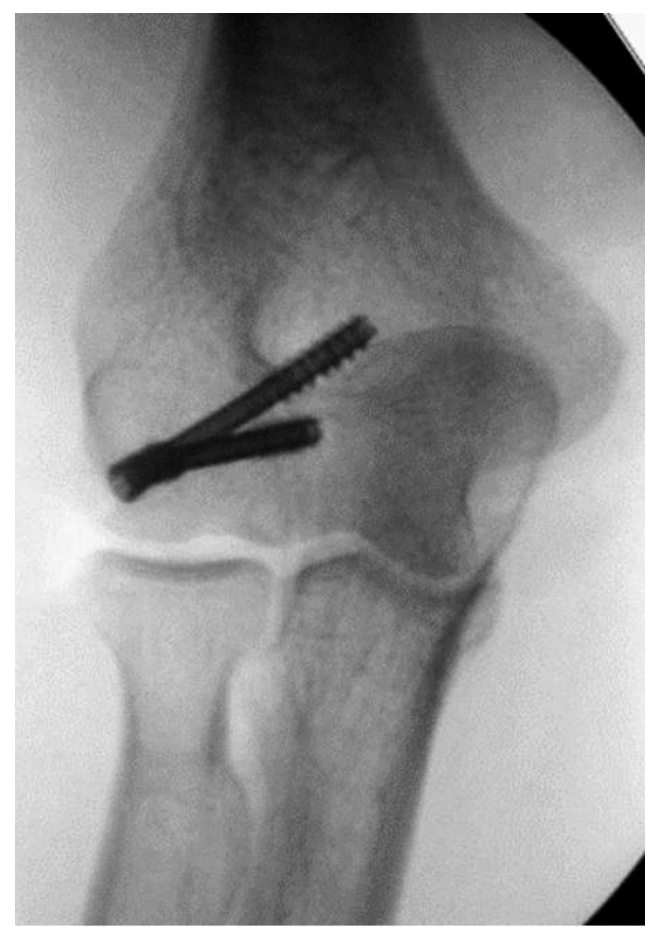

1. ábra

Csavaros rögzítés

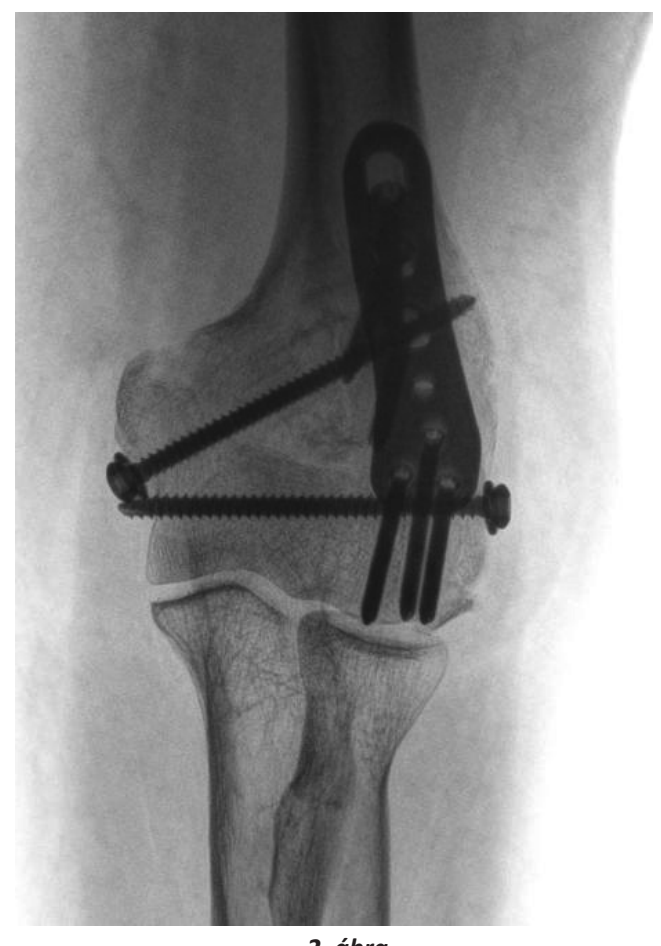

2. ábra

Egyoldali lemezelés csavarozással kiegészítve

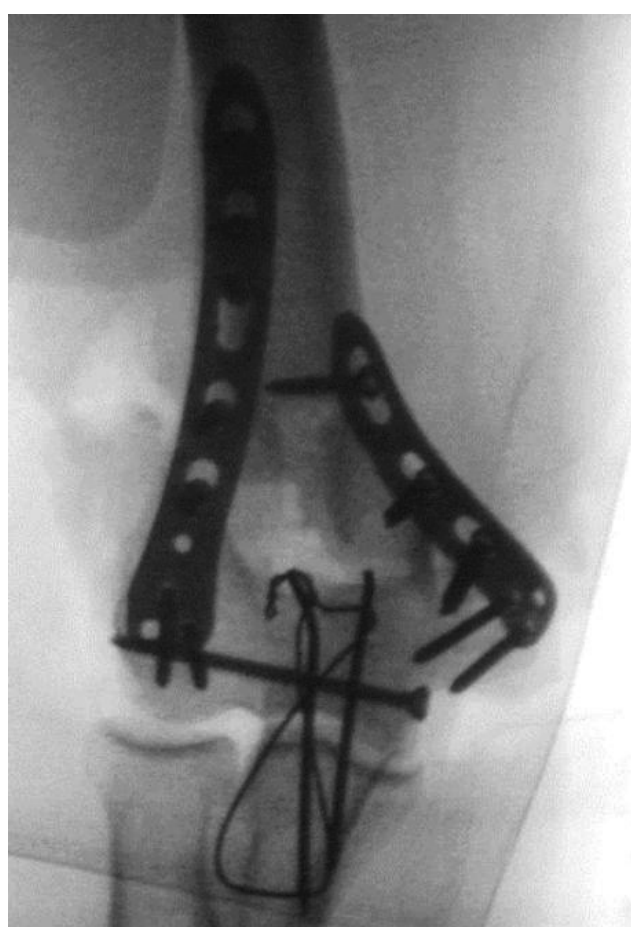

3. ábra

Kettős lemezelés olecranon osteotomiával 


\section{EREDMÉNYEK}

A vizsgált időintervallumban 53 beteget operáltunk humerus distalis vég törése miatt. Az átlagéletkor 61 év volt. A sérültek 73,5\%-a nő volt. A kérdőív kitöltésekor a mútét után 12-24 hónap telt el, így eredményeiket már végleges állapotként kezeltük.

A törés típusa szerint csoportosítva 15 A, 18 $B$ és 20 C típusú töréssel találkoztunk. Az átlag QD pontérték az A típusú törések esetében 23,51, B típusú töréseknél 19,76 és a C típusúaknál 16,57 volt (4. ábra). Az átlag fájdalomérték az $A$ törések esetében 1,88 , a $B$ törések esetében 2,8 , míg a $C$ törések esetében 1,3 volt (5. ábra). Az elégedettségi szint a következőkképpen alakult: $A$ töréseknél 8,7; B töréseknél 9,1; C töréseknél 9,7 (6. ábra).

A repozíció minősége szerinti 3 csoport megoszlása: 10 pontos (anatómiai) volt a repozítcója 34 betegnek, 9 pontos (közel anatómiai) 13 betegnek, valamint 8 pontot 6 beteg posztoperatív helyzete kapott. Az 10 pontos csoportban a QD érték 16,47, a fájdalom 1,9,

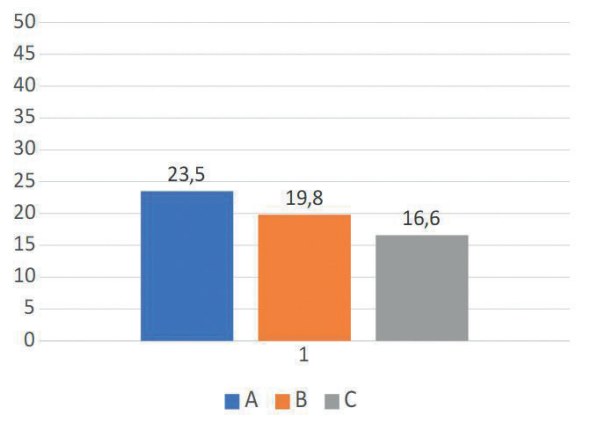

4. ábra

QuickDASH értékek átlaga a törés típusa szerint

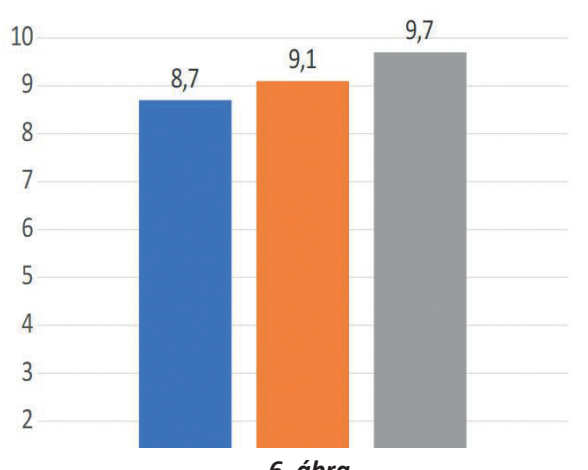

Elégedettség mértékének átlaga a törés típusa szerint (VAS) az elégedettség pedig 9,35 volt. A közel anatómiai csoportban a következőként alakultak az eredmények: QD érték 28,03, a fájdalom 2,16, az elégedettség 8,83. Amennyiben az ízületi felszínt nem sikerült maradéktalanul helyreállítani, vagy a humerus-trochlea szög az anatómiaitól eltérő maradt, a QD érték 25,73, fájdalom mértéke 2,33 és az elégedettség 9 pontként alakult (7-9. ábrák).

A behelyezett implantátum szerint csoportosítva: 23 beteg esetén csavaros osteosynthesis, 7 beteg esetén egyoldali lemez és kiegészítő csavarok, és 21 sérültnél olecranon osteotomiával, kettős lemez behelyezése történt. Csavaros synthesis mellett a QD érték 23,34, a fájdalom mértéke 2,72 és az elégedettségi szint 8,72 volt. Az egyoldali lemezelés csavarozással kiegészítve a következő eredményekhez vezetett: QD 31,36, fájdalom 2,4 , elégedettség 8,8. Kettős lemezeléssel az átlagértékek a következőkként alakultak: QD 12,42, a fájdalom 1,23, az elégedettség 9,77 (10-12. ábrák).

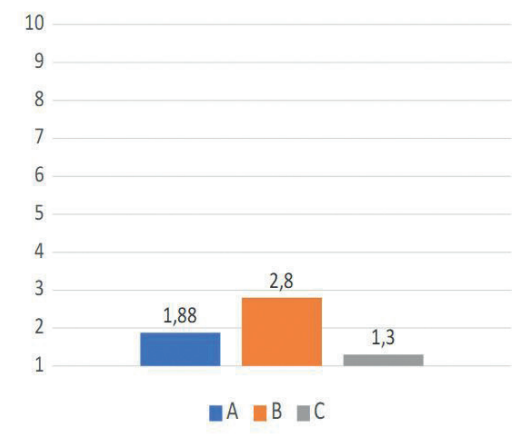

5. ábra

Fájdalom mértékének átlaga a törés típusa szerint (VAS)

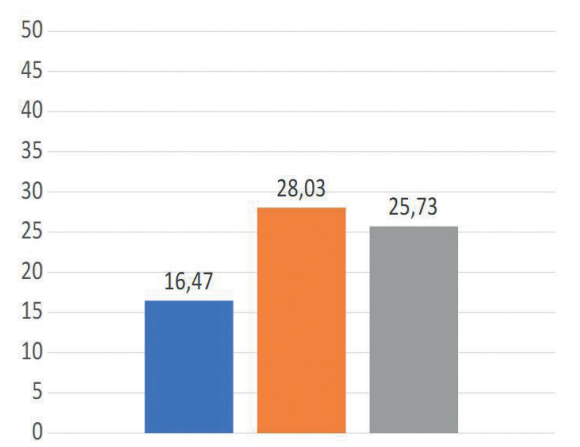

7. ábra

QuickDASH értékek átlaga a repozíció minősége szerint 


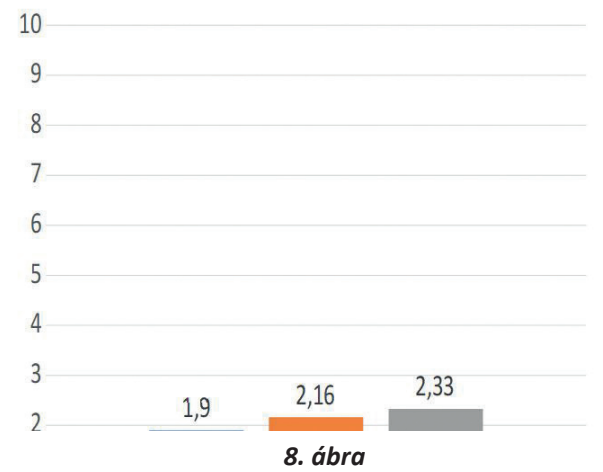

Fájdalom mértékének átlaga a repozíció minősége szerint (VAS)

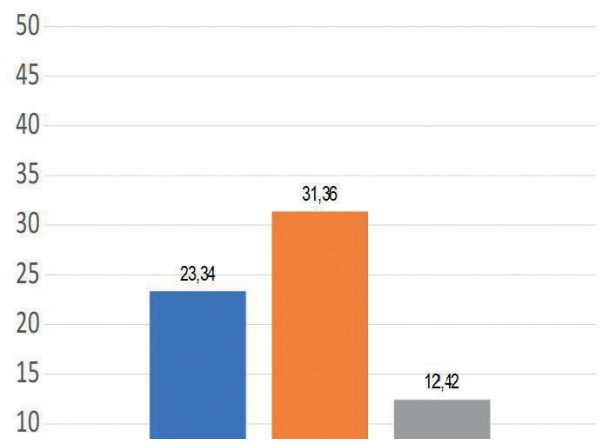

10. ábra

QuickDASH értékek átlaga a behelyezett implantátumok szerint

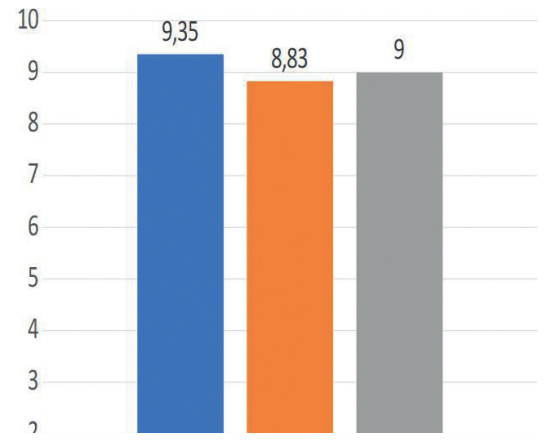

9. ábra

Elégedettség mértékének átlaga a repozició minősége szerint (VAS)

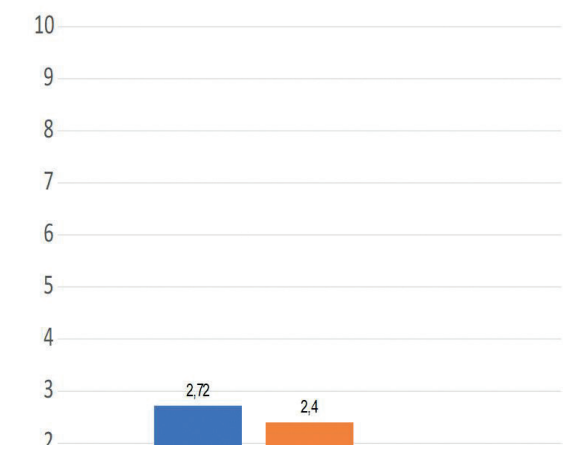

11. ábra

Fájdalom mértékének átlaga a behelyezett implantátumok szerint

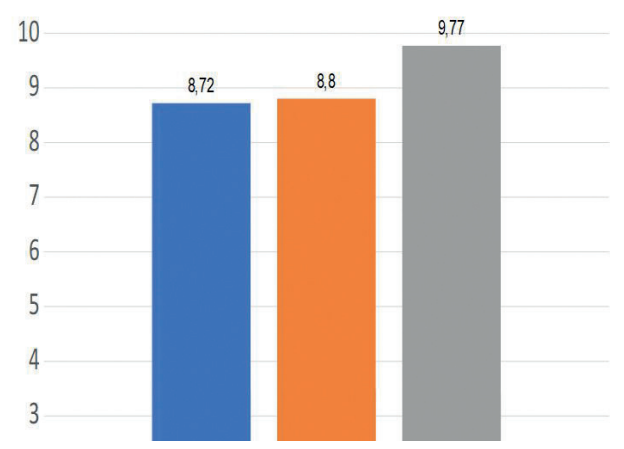

12. ábra

Elégedettség mértékének átlaga a behelyezett implantátumok szerint 


\section{MEGBESZÉLÉS}

Szignifikáns különbséget találtunk a törés típusa szerint csoportosítva a C típusú törések esetében. Várakozásunkkal ellentétben a C típusú törések QuickDASH értéke szignifikánsan alacsonyabb volt, tehát a funkcionális eredményük sokkal jobb volt. Az átlag fájdalomértékük szignifikánsan alacsonyabb, és az elégedettségük szintje pedig szignifikánsan magasabb volt a másik két csoporthoz képest. Ezen eredmény valószínúleg a kiterjedtebb feltárással elért pontos repozíció és mozgásstabil synthesis számlájára írható, amely a nemzetközi publikációk eredményeivel egybecseng $(2,6)$.

A repozíciós helyzet tekintetében egyedül a QuickDASH pontérték volt szignifikánsan alacsonyabb az anatómiai repozíciós helyzet esetében a másik két csoporthoz viszonyítva.

A behelyezett implantátum vonatkozásában a kettős lemezelés esetében észleltünk szignifikánsan alacsonyabb QuickDASH és fájdalomértéket, valamint szignifikánsan magasabb elégedettségi szintet. Ezt könnyen magyarázhatja a kettős lemezelés biomechanikájából eredő kifejezett stabilitás (5), valamint az, hogy kiterjedt Lexer feltárást alkalmazunk olecranon osteotomiával, amely pontos repozíciót tesz lehetővé.

Összegzésként elmondhatjuk, hogy ebben a régióban kiemelten fontos az $\mathrm{AO}$ alapelvek szerepe. Eredményeink alátámasztották, hogy jó repozíciós helyzettel és mozgásstabil synthesissel jó funkcionális eredményt, alacsonyabb fájdalomszintet és magasabb elégedettséget várhatunk sérültjeinktől.

\section{IRODALOM}

1. Athwal G. S.: Distal humerus fractures. In: Court-Brown C., Heckman J., McQueen M., Ricci W., Tornetta III P. (Eds.): Rockwood and Green's fractures in adults. 8. Ed. Philadelphia. Wolters Kluwer. 2015. 1229-1286 p.

2. Chen $H_{\text {., }} \mathrm{Li}$ D., Zhang J., Xiong $X$.: Comparison of treatments in patients with distal humerus intercondylar fracture: a systematic review and meta-analysis. Ann. Med. 2017. 49. (7): 613-625. https://doi.org/10.1080/07853890.2017.1335429

3. Fekete K.: Humerus distalis vég törése. Könyökficam. Myositis ossificans. In: Renner A. (Szerk.): Traumatológia. Budapest. Medicina. 2011. 501-516. $p$.

4. Lauder A., Richard M. J.: Management of distal humerus fractures. Eur. J. Orthop. Surg. Traumatol. 2020. 30. (5): 745-762. https://doi.org/10.1007/s00590-020-02626-1

5. Michel P. A., Katthagen J. C., Heilmann L. F., Dyrna F., Schliemann B., Raschke M. J.: Biomechanics of upper extremity double plating. Z. Orthop. Unfall. 2020. 158. (2): 238-244. https://doi.org/10.1055/a-0862-6334

6. Pantalone A., Vanni D., Guelfi M., Belluati A., Salini V.: Double plating for bicolumnar distal humerus fractures in the elderly. Injury. 2017. 48. Suppl. 3: S20-S23. https://doi.org/10.1016/S0020-1383(17)30652-6

7. Plath J. E., Förch S., Haufe T., Mayr E. J.: Distal humerus fracture in the elderly. Z. Orthop. Unfall. 2018. 156. (1): 30-40. https://doi.org/10.1055/s-0043-121893

8. Sharma S., John R., Dhillon M. S., Kishore K.: Surgical approaches for open reduction and internal fixation of intraarticular distal humerus fractures in adults: A systematic review and meta-analysis. Injury. 2018. 49. (8): 1381-1391. https://doi.org/10.1016/j.injury.2018.06.018

\section{Dr. Lakatos Adrienn}

B.-A.-Z. Megyei Központi Kórház és Egyetemi Oktató Kórház

Traumatológiai Osztály

3526 Miskolc, Szentpéteri kapu 72-76. 